\title{
Fungi of the genus Fusarium as pathogens of soybean seedlings
}

\author{
JOANNA MARCINKOWSKA
}

Department of Plant Pathology, Agricultural University of Warsaw - SGGW - AR, ul. Nowoursynowska 166, 02-766 Warszawa, Poland

(Received: August 2, 1984)

\begin{abstract}
Twenty isolates of fungi of the genus Fusarium collected in the period 1980-1982 from various organs of diseased soybean plants were investigated. Eight of them proved pathogenic to soybean seedlings. The species $F$. culmorum was most numerously represented among the isolated ( 4 of 8 ) pathogens. Isolates of $F$. sambucinum were also pathogenic ( 2 of 4 ) and those of $F$. soloni ( 1 of 3$)$, too. The only isolate of $F$. avenaceum also caused seedling blight. Two isolates of $F$. oxysporum and two of $F$. arthrosporioides were not pathogenic. Numerous isolates affected seed germination and one greatly inhibited growth of the infected seedlings. Pathogenicity was tested in the laboratory in Petri plates on isolate cultures and on filter paper imbibed with fungal inoculum and, in the greenhouse on a peat and perlite substrate. The degree of infection and the character of the disease symptoms depended on the experimental conditions. The results of experiments in plates and in the greenhouse supplemented one another.
\end{abstract}

\section{INTRODUCTION}

Fungi of the Fusarium genus produce diseases in soybean (Glycine max (L.) Merril) cultivated in various countries. They have been the cause of seedling blight (V a r d a n i y a, 1971; S a h a r a n and G u p t a, 1972; S e r e b r e n n i ova, 1978) and blight of older plants (D u n le a v y, 1961; F r e n ch and $\mathrm{Ke} \mathrm{n} \mathrm{ned} \mathrm{y,} \mathrm{1963;} \mathrm{S} \mathrm{c} \mathrm{he} \mathrm{n} \mathrm{c} \mathrm{k} \mathrm{and} \mathrm{K} \mathrm{i} \mathrm{n} \mathrm{lo} \mathrm{ch,}$ 1974). The species $F$. oxysporum Schlecht. is responsible for fusarium wilt of soybean (M a t s u o et al., 1959; A r m s trong and A r m s r on g, 1965: L e a $\mathrm{h}$ and $\mathrm{C}$ a $\mathrm{r}$ o 11,1982 ). Numerous Fusarium species may be also found on soybean seeds (W u et al., 1964; $\mathrm{S} \mathrm{i} \mathrm{n} \mathrm{g} \mathrm{h} \mathrm{et} \mathrm{al.,} \mathrm{1973;}$ $\mathrm{T}$ e $\mathrm{n} \mathrm{n}$ e et al., 1974). In Poland soybean seed infection was more frequent (P i e t k i e w i c z, 1959; Śląz a k, 1978; D z i ę g i e le w s k a, 1980) than that of seedlings (B i e l e c k a, 1978). 
In the USA $\mathrm{Fren} \mathrm{ch}$ and $\mathrm{K}$ e $\mathrm{n} n \mathrm{ed} \mathrm{y}$ (1963), $\mathrm{W}$ a r e $\mathrm{n}$ and $\mathrm{K}$ o $\mathrm{m} \mathrm{m} \mathrm{e} \mathrm{d} \mathrm{a} \mathrm{h} 1$ (1973) expressed different opinions as regards the pathogenicity and harmful influence of fungi of the genus Fusarium appearing on soybean. These controversies resulted from the influence of conditions under which the plants grew (R o s s, 1965; $\mathrm{K}$ i l p a t r i c k and $\mathrm{Har}$ t w i g; 1955; $\mathrm{W}$ a r r e $\mathrm{n}$ and $\mathrm{K}$ o $\mathrm{m} \mathrm{m}$ e d a h l, 1973). The pathogenicity of the tested fungal isolates may have also been important ( $\mathrm{N} \mathrm{y} \mathrm{v} \mathrm{a} \mathrm{11,} \mathrm{1976;}$ B i e l e c k a, 1978; K a s p e r o w i c z, 1982).

Recently several Fusarium species have been isolated from soybean in Poland. They were obtained from diseased plant organs beside other fungal species (M a r c i n k ow s k a et al., 1982), especially Phoma exigua var. exigua (M a r c i n k o w s k a, 1984). In the present study, which is a further step in investigations on the etiology of soybean diseases, particular attention was devoted to isolates of fungi of the genus Fusarium. To determine their pathogenicity, the influence of the isolates on seed germination and seedling infection was tested in laboratory conditions as well as the influence of these fungi on infection and growth of seedlings in a greenhouse experiment.

\section{MATERIAL AND METHODS}

Fungi of the genus Fusarium were isolated in the period 1980-1982 from the hypocotyl and epicotyl of soybean (Glycine max (L.) Merril) seedlings showing symptoms of blight (islolates S), from the root neck of older seedlings (SK) and root neck and stem of ripening plants (L) as well as from seeds overgrown with mycelium (N) (Table 1). Twenty isolates were obtained from infected soybean plants cultivated in various regions of Poland. The object investigated consisted of soybean plots of the Institute of Plant Breeding and Acclimatization at Radzików and soybean fields of agricultural experimental stations. The isolates were cultures on potato dextrose agar (PDA) at $10^{\circ} \mathrm{C}$ and identified according to B o o t h's key (1971). Soybean seeds of the variety 'Progres', desinfected for 3 min in 70 per cent ethyl alcohol, were used for the experiments.

The laboratory experiments were run in Petri plates $10 \mathrm{~cm}$ in diametre, with eight seeds in each and incubated in a dark thermostat at $25^{\circ} \mathrm{C}$ for seven days. Each combination was replicated five times. In the first experiment the seeds were placed on a week-old culture of the particular fungus isolate. In the second the seeds were sown on filter paper imbibed with inoculum $(6 \mathrm{ml} / \mathrm{plate})$ of the tested fungus. The inoculum consisted of a suspension of 2 million spores in $1 \mathrm{ml}$ of water. The suspension was prepared after filtering off the mycelium from 2-week liquid cultures in mineral medium ( $\mathrm{K}$ e $\mathrm{r} \mathrm{r}, 1963)$. After seven days the number of ungerminated healthy seeds and those overgrown with mycelium was determined, and the number of healthy and infected seedlings. Infection was evaluated according to a 4-degree score: 0 - healthy seedlings, 1 - blight at ends 
of main and lateral roots or their fragments, 2 - blight of root neck or at least one half of the root length, 3 - whole root infected.

The greenhouse experiments were done in $15-\mathrm{cm}$ diametre pots filled with peat or perlite. Each pot was considered as a replication. Into each pot eight germinating seeds were sown. On the next day the seeds were watered with the same kind of inoculum as in the laboratory experiments. One mililitre of inoculum was used per $1 \mathrm{~cm}^{2}$ of substrate. Plants in four pots with perlite and four pots with peat were inoculated with a suspension of spores from each isolate. Infection was evaluated two weeks after seedling inoculation according to the mentioned 0-4 score. At the same time the lengths of roots and stems of the in oculated plants were measured.

The influence of the fungi on seed germination, growth and seedling infection was evaluated on the basis of one-way analysis of variance. Duncan's test one-way was applied for comparing seed germination and two-way for comparing plant growth with controls. The significance of the differences between the infection of inoculated seedlings was established by means of Tukey's t test.

Ta b 1 e 1

Characteristic of isolates of tested Fusarium species from soybean

\begin{tabular}{|c|c|c|c|c|}
\hline \multirow[b]{2}{*}{ Isolate } & \multirow[b]{2}{*}{ Fungus species } & \multicolumn{3}{|c|}{ Origin of isolate } \\
\hline & & plant organ & $\begin{array}{l}\text { year of } \\
\text { isolation }\end{array}$ & locality \\
\hline S 1 & $F$. arthrosporioides & seed lings hypocotyl & 1980 & Radzików \\
\hline S 2 & F. sambucinum & $"$ & 1980 & Radzików \\
\hline S 3 & F. oxysporum & $"$ & 1980 & Ursynów \\
\hline S 4 & F. sambucinum & seed lings epicotyl & 1980 & Radzików \\
\hline S 5 & F. sambucinum & $"$ & 1981 & $\begin{array}{l}\text { Rakowiecka } \\
\text { szklarnia }\end{array}$ \\
\hline S 6 & F. culmorum & seedling hypocotyl & 1981 & Radzików \\
\hline S 7 & F. culmorum & hypocotyl and epicotyl & 1981 & Radzików \\
\hline S 8 & F. solani & hypocotyl & 1982 & Radzików \\
\hline SK 1 & F. culmorum & root neck of seedling & 1981 & Radzików \\
\hline SK 2 & F. avenaceum & $"$ & 1982 & Radzików \\
\hline L 1 & F. culmorum & root neck of plant & 1980 & Łosiów \\
\hline L 2 & F. culmorum & $"$ & 1980 & Bogusławice \\
\hline L 3 & F. culmorum & $"$ & 1981 & Jank owice \\
\hline L 4 & F. sambucinum & $"$ & 1982 & Breń \\
\hline N 1 & F. culmorum & seed & 1980 & Radzików \\
\hline N 2 & F. culmorum & $"$ & 1980 & Jank owice \\
\hline N 3 & F. arthrosporioides & $"$ & 1980 & Radzików \\
\hline N 4 & $F$. oxysporum & $"$ & 1980 & Illinois, USA \\
\hline N 5 & F. solani & $"$ & 1981 & Jankowice \\
\hline N 6 & F. solani & $"$ & 1982 & Radzików \\
\hline
\end{tabular}




\section{RESULTS}

F. culmorum (W. G. Smith) Sacc. dominated among the species of the genus Fusarium isolated from infected soybeans (Table 1). Eight isolates of this species were obtained from all the examined parts of plants (S6, S7, SK1, L1, L2, L3, N1, N2) cultivated in various regions of Poland. There were also isolated four isolates of $F$. sambucinum Fuckel, three of $F$. solani (Mart.) Sacc., two from each $F$. oxysporum Schlecht. and $F$. arthrosporioides Sherb. and one from $F$. avenaceum (Fr.) Sacc.

\section{$\mathrm{T}$ a b 1 e 2}

Influence of various Fusarium isolates on germination of seeds infected in two ways

\begin{tabular}{|c|c|c|c|c|c|}
\hline & & \multicolumn{4}{|c|}{ Seeds placed on } \\
\hline \multirow{3}{*}{ Fungus species } & \multirow{3}{*}{ Isolate } & \multicolumn{2}{|c|}{ fungus culture } & \multicolumn{2}{|c|}{$\begin{array}{l}\text { filter paper with } \\
\text { inoculum }\end{array}$} \\
\hline & & \multicolumn{4}{|c|}{ number of nongerminating seeds } \\
\hline & & infected & noninfected & infected & noninfected \\
\hline Control combination & & 0 & 0.8 & 0 & 0.2 \\
\hline F. oxysporum & S 3 & $0.2 \mathrm{a}$ & & 0.8 & \\
\hline F. arthrosporioides & N 3 & $0.4 \mathrm{a}$ & & 0 & \\
\hline F. solani & N 6 & $0.6 \mathrm{a}$ & & 1.4 & \\
\hline F. solani & S 8 & $1.2 \mathrm{a}$ & & 1.2 & \\
\hline F. sambucinum & S 4 & $1.4 \mathrm{a}$ & & 1 & \\
\hline F. culmorum & N 1 & $2.2 \mathrm{a}$ & & 0 & \\
\hline F. sambucinum & S 5 & $2.2 \mathrm{a}$ & & 0 & \\
\hline F. solani & N 5 & $2.2 \mathrm{a}$ & & 0.4 & \\
\hline F. culmorum & S 7 & $2.2 \mathrm{a}$ & & 0.8 & \\
\hline F. culmorum & L 3 & 2.2 a & & 0.8 & \\
\hline F. culmorum & L 1 & $2.4 \mathrm{a}$ & $\cdot$ & 0.8 & \\
\hline F. oxysporum & N 4 & $2.4 \mathrm{a}$ & & 1.2 & \\
\hline F. sambucinum & S 2 & $2.6 \mathrm{a}$ & & 0.6 & \\
\hline F. arthrosporioides & S 1 & $3.0 \mathrm{a}$ & & 0.4 & \\
\hline F. culmorum & L 2 & $3.6 \mathrm{~b}$ & & 0.4 & \\
\hline F. culmorum & N 2 & $3.6 \mathrm{~b}$ & & 0.6 & \\
\hline F. sambucinum & L 4 & $3.8 \mathrm{~b}$ & & 0 & \\
\hline F. culmorum & SK 1 & $3.8 \mathrm{~b}$ & & 0.4 & \\
\hline F. culmorum & S 6 & $4.2 \mathrm{~b}$ & & 1 & \\
\hline F. avenaceum & SK 2 & $6.2 \mathrm{~b}$ & & 0.6 & . \\
\hline $\begin{array}{l}\text { LSD according to Tuk } \\
\text { for } x=0.05\end{array}$ & & 2.4 & . & $\begin{array}{l}\text { insignifican } \\
\text { differences }\end{array}$ & \\
\hline
\end{tabular}




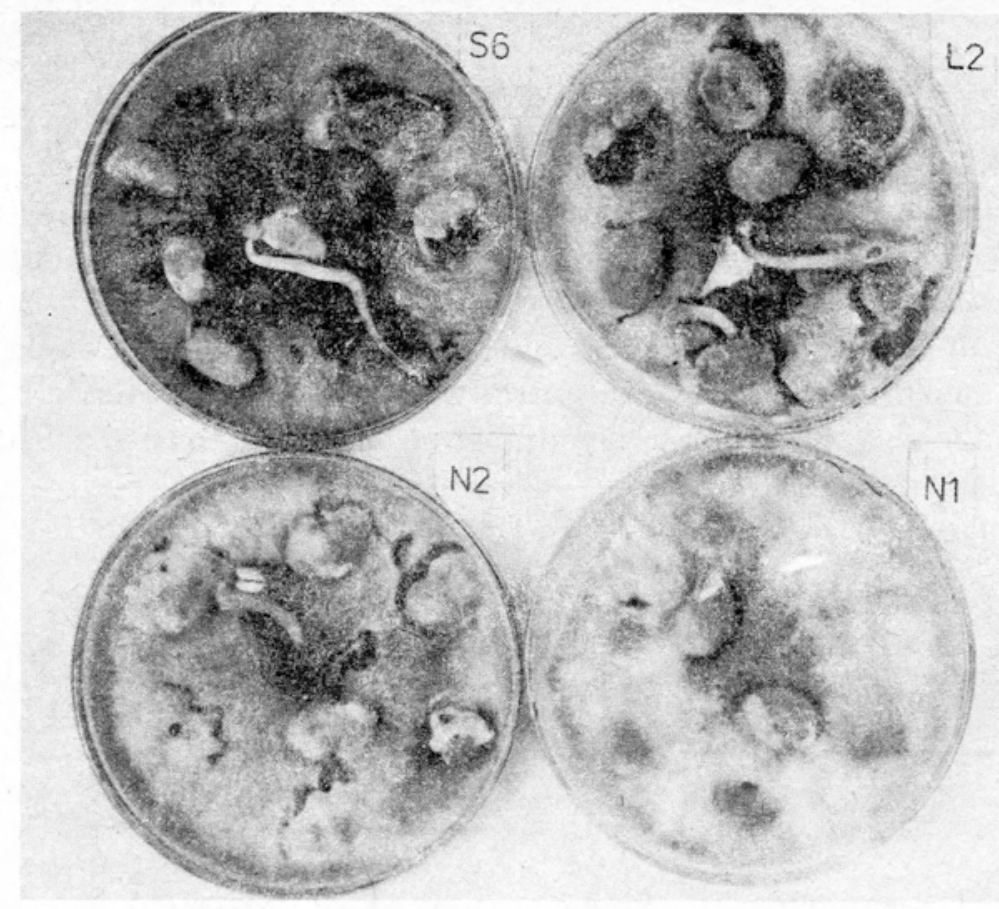

Fig. 1. Soybean seeds and seedlings infected with various isolates (S6, L2, N2, N1) of Fusarium culmorum

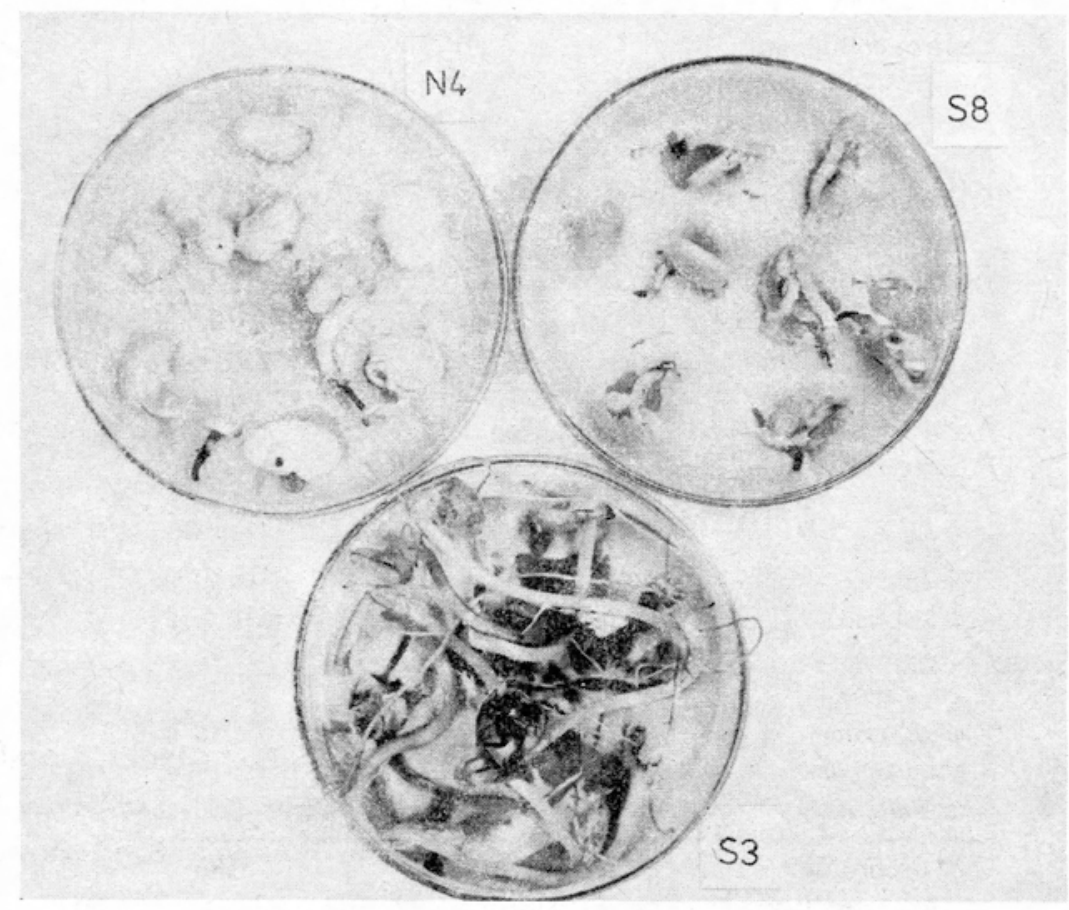

Fig. 2. Soybean seeds and seedlings infected by isolates (N4 and S3) of Fusarium oxysporum and (S8) Fusarium solani 
The tested isolates mostly inhibited soybean seed germination (Table 2). Six of them: S6, SK 1, N2, L2 (F.culmorum), SK2 (F. avenaceum) and L4 (F. sambucinum) depressed significantly seed germination (Figs. 1 and 2 ) as compared with that on uninfected medium. Seeds placed on filter paper imbibed with inoculum from $F$. sambucinum isolates (S4, L4), F. culmorum (N1) and F. arthrosporioides (N3) germinated in 100 per cent, whereas in the remaining combinations a small number of ungerminated seeds overgrown with mycelium was observed. The depressive influence of fungi on seed germination was found to be nonsignificant under the conditions of this test.

Ta b l e 3

Soybean seedling infection by inoculation with Fusarium isolates in laboratory experiments

\begin{tabular}{|c|c|c|c|}
\hline \multirow{3}{*}{ Fungus species } & \multirow{3}{*}{ Isolate } & \multicolumn{2}{|c|}{ Infection degree, $0-3$ score } \\
\hline & & \multicolumn{2}{|c|}{$\begin{array}{l}\text { seedling infected } \\
\text { by placing seeds on }\end{array}$} \\
\hline & & $\begin{array}{l}\text { fungus } \\
\text { culture }\end{array}$ & $\begin{array}{l}\text { filter paper with } \\
\text { inoculum }\end{array}$ \\
\hline Control combination & & 0 & 0 \\
\hline F. oxysporum & S 3 & $0.90 \mathrm{a}$ & $0.14 \mathrm{a}$ \\
\hline F. arthrosporioides & S 1 & $1.18 \mathrm{a}$ & $0.54 \mathrm{a}$ \\
\hline F. solani & N 6 & $1.32 \mathrm{a}$ & $0.36 \mathrm{a}$ \\
\hline F. sambucinum & S 4 & $1.72 \mathrm{a}$ & $0.58 \mathrm{a}$ \\
\hline F. arthrosporioides & N 3 & $1.78 \mathrm{~b}$ & $1.30 \mathrm{~b}$ \\
\hline F. culmorum & L 3 & $1.80 \mathrm{~b}$ & $1.62 \mathrm{~b}$ \\
\hline F. sambucinum & S 2 & $1.86 \mathrm{~b}$ & $0.32 \mathrm{a}$ \\
\hline F. culmorum & N 2 & $2.10 \mathrm{~b}$ & $0.60 \mathrm{a}$ \\
\hline F. culmorum & L 2 & $2.14 \mathrm{~b}$ & $2.76 \mathrm{c}$ \\
\hline F. culmorum & SK 1 & $2.16 \mathrm{~b}$ & $0.62 \mathrm{a}$ \\
\hline F. sambucinum & S 5 & $2.22 \mathrm{~b}$ & $2.86 \mathrm{c}$ \\
\hline F. solani & S 8 & $2.26 \mathrm{~b}$ & $2.52 \mathrm{c}$ \\
\hline F. culmorum & N 1 & $2.28 \mathrm{~b}$ & $3 \mathrm{c}$ \\
\hline F. solani & N 5 & $2.30 \mathrm{~b}$ & $1.20 \mathrm{~b}$ \\
\hline F. culmorum & S 6 & $2.40 \mathrm{~b}$ & $2.74 \mathrm{c}$ \\
\hline F. culmorum & L 1 & $2.46 \mathrm{~b}$ & $2.96 \mathrm{c}$ \\
\hline F. culmorum & S 7 & $2.52 \mathrm{~b}$ & $0.56 \mathrm{a}$ \\
\hline F. oxysporum & N 4 & $2.56 \mathrm{~b}$ & $1.36 \mathrm{~b}$ \\
\hline F. sambucinum & L 4 & $2.74 \mathrm{c}$ & $3 \mathrm{c}$ \\
\hline$F$. avenaceum & SK 2 & $3 \mathrm{c}$ & $2.86 \mathrm{c}$ \\
\hline $\begin{array}{l}\text { LSD according to Tu } \\
\text { for } \alpha=0.05\end{array}$ & test & 0.85 & 0.86 \\
\hline
\end{tabular}




\section{T a b l e 4}

Infection of soybean seedlings by various Fusarium species in greenhouse experiments

\begin{tabular}{|c|c|c|c|}
\hline \multirow{3}{*}{ Fungus species } & \multirow{3}{*}{ Isolate } & \multirow{2}{*}{\multicolumn{2}{|c|}{$\frac{\text { Degree of infection, } 0-3 \text { score }}{\text { seedlings grown on }}$}} \\
\hline & & & \\
\hline & & perlite & peat \\
\hline Control combination & & 0 & $\mathbf{0}$ \\
\hline F. oxysporum & S 3 & $0.05 \mathrm{a}$ & $0.42 \mathrm{a}$ \\
\hline F. sambucinum & S 2 & $0.15 \mathrm{a}$ & $0.20 \mathrm{a}$ \\
\hline F. culmorum & N 2 & $0.15 \mathrm{a}$ & $0.25 \mathrm{a}$ \\
\hline F. solani & N 6 & $0.15 \mathrm{a}$ & $0.85 \mathrm{a}$ \\
\hline F. culmorum & S 7 & $0.20 \mathrm{a}$ & $0.10 \mathrm{a}$ \\
\hline F. oxysporum & N 4 & 0.22 a & $0.48 \mathrm{a}$ \\
\hline F. sambucinum & S 4 & $0.25 \mathrm{a}$ & $0.30 \mathrm{a}$ \\
\hline F. culmorum & SK 1 & $0.25 \mathrm{a}$ & $0.58 \mathrm{a}$ \\
\hline F. arthrosporioides & S 1 & $0.28 \mathrm{a}$ & 0.42 a \\
\hline F. solani & N 5 & $0.30 \mathrm{a}$ & 0.22 a \\
\hline F. culmorum & L 3 & 0.35 a & 0.45 a \\
\hline F. arthrosporioides & N 3 & 0.35 a & $0.55 \mathrm{a}$ \\
\hline$F$. solani & S 8 & $0.40 \mathrm{a}$ & $0.60 \mathrm{a}$ \\
\hline F. culmorum & L 2 & $0.42 \mathrm{a}$ & $0.85 \mathrm{a}$ \\
\hline F. avenaceum & SK 2 & $0.42 \mathrm{a}$ & $1.18 \mathrm{~b}$ \\
\hline F. culmorum & S 6 & $0.70 \mathrm{~b}$ & $0.32 \mathrm{a}$ \\
\hline F. culmorum & L 1 & $0.82 \mathrm{~b}$ & $0.68 \mathrm{a}$ \\
\hline F. sambucinum & L 4 & $0.85 \mathrm{~b}$ & $0.65 \mathrm{a}$ \\
\hline F. sambucinum & S 5 & $1.60 \mathrm{c}$ & $0.40 \mathrm{a}$ \\
\hline F. culmorum & N 1 & $20 \mathrm{c}$ & $1.02 \mathrm{~b}$ \\
\hline
\end{tabular}

LSD according to Tukey's $t$ test for $\alpha=0.05$

The isolates of Fusarium species tested in both laboratory experiments were divided into three groups ( $a, b$ and $c$ ) differing in pathogenicity (Table 3 ). The results were most consistent in the plate tests for some extreme and medium values. Strongly pathogenic isolates of group c were L4 (F. sambucinum) and SK2 $(F$. avenaceum), and in the test on filter paper six other isolates. The degree of infection of seedlings by the tested isolates in the plate tests was higher than in greenhouse experiments (Tables 3 and 4).

The results of the experiment with peat as substrate allowed to distinguish only two groups $(a, b)$ of isolates with significantly differing pathogenicity and on perlite three groups $(a, b$ and $c)$. Infection of the inoculated seedlings on perlite was weaker than of those on peat (Table 4$)$. Isolate N1 $(F$. culmorum) proved most 


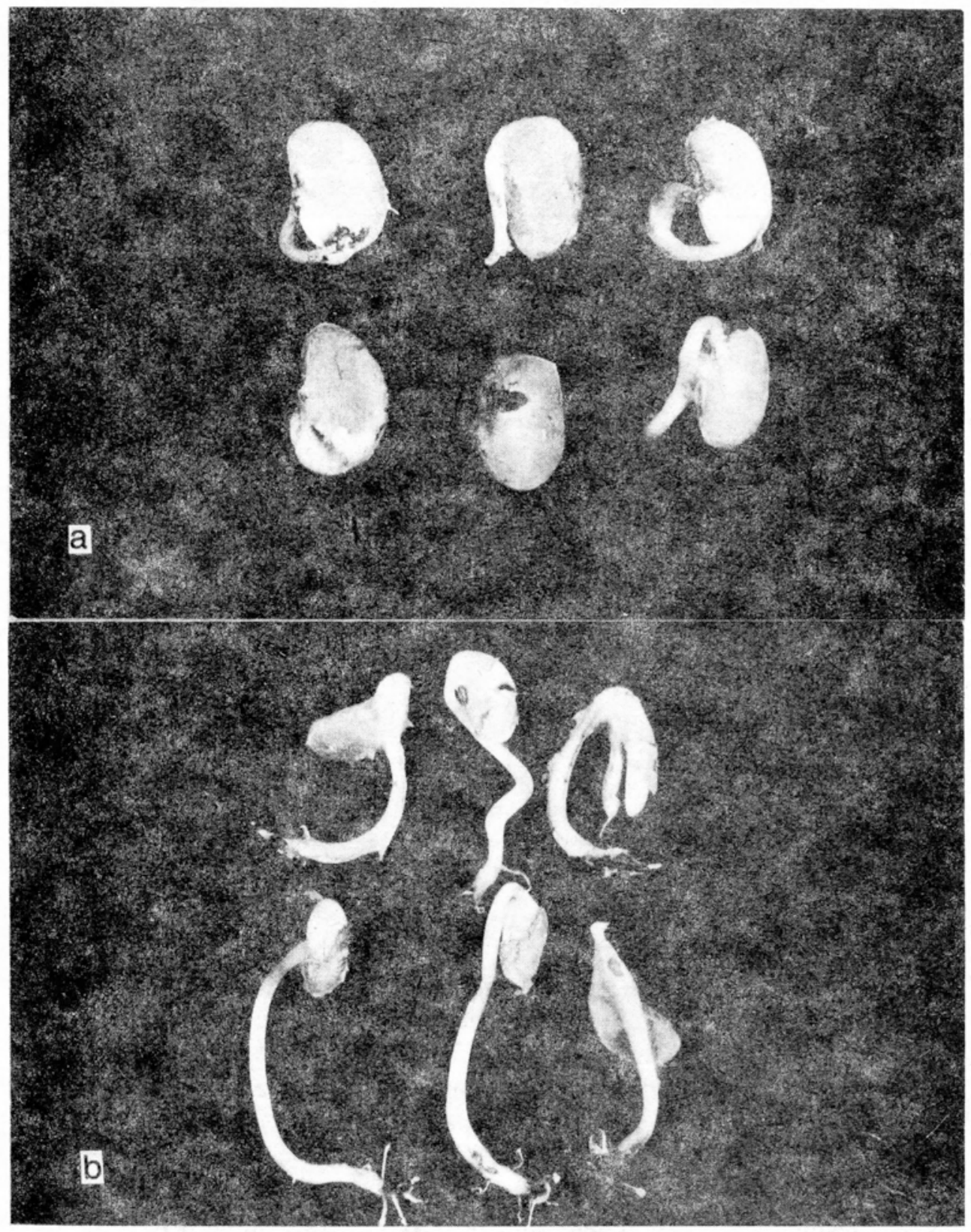

Fig. 3. Sprout (a) and root (b) blight in soybean caused by F. culmorum (isolate N1) 


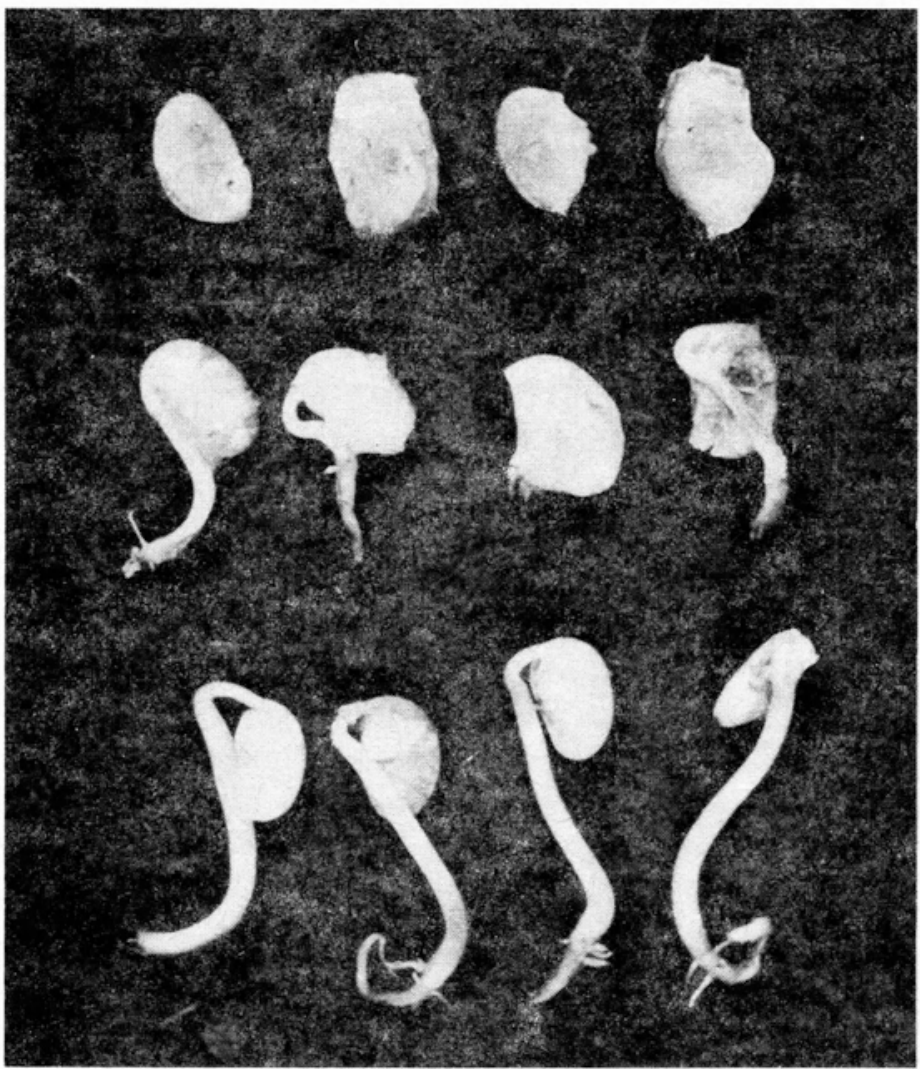

Fig. 4. Seed germination inhibition and sprout and root blight in soybean seedlings caused by F. sambucinum (isolate $\mathrm{S} 5$ )

pathogenic to seedlings grown on perlite (group c) as well as on peat (group b). The pathogenicity of other isolates, for instance S5 (F. sambucinum) and SK2 $(F$. avenaceum) differed in dependence on the way of plant cultivation (Figs. 3 and 4).

Isolates of the tested Fusarium species influenced but little the growth of the plant expressed in shoot and root length (Table 5). Only isolate N1 (F.culmorum) distinctly inhibited shoot and root growth in the seedlings on perlite, and only root growth of the plants growing on peat.

\section{DISCUSSION}

Fungi of the genus Fusarium occur on soybean only sporadically in Poland. Evidence of this is the small number of isolates obtained from various plant organs. D z i ę g i e 1 e w s k a (1980) collected the largest number of isolates 
Ta ble 5

Growth of soybean seedlings on two substrates in greenhouse after their inoculation with Fusarium species isolates

\begin{tabular}{|c|c|c|c|c|c|}
\hline \multirow{3}{*}{$\begin{array}{l}\text { Fungus species and } \\
\text { isolate symbol }\end{array}$} & & \multicolumn{2}{|c|}{ Plants on perlite } & \multicolumn{2}{|c|}{ Plants on peat } \\
\hline & & \multicolumn{4}{|c|}{ mean length, $\mathrm{cm}$} \\
\hline & & root & shoot & root & shoot \\
\hline Control combination & & $19.3 \mathrm{~b}$ & $10.4 \mathrm{~b}$ & $18.1 \mathrm{~b}$ & $13.9 \mathrm{a}$ \\
\hline F. culmorum & N 1 & $6.2 \mathrm{a}$ & $3.5 \mathrm{a}$ & $14.0 \mathrm{a}$ & $11.2 \mathrm{a}$ \\
\hline F. oxysporum & S 3 & $16.9 \mathrm{~b}$ & $11.3 \mathrm{~b}$ & $18.9 \mathrm{~b}$ & $13.0 \mathrm{a}$ \\
\hline$F$. solani & N 6 & $17.8 \mathrm{~b}$ & $11.2 \mathrm{~b}$ & $17.2 \mathrm{~b}$ & $10.8 \mathrm{a}$ \\
\hline F. sambucinum & S 2 & $18.3 \mathrm{~b}$ & $12.5 \mathrm{~b}$ & $17.6 \mathrm{~b}$ & $14.5 \mathrm{a}$ \\
\hline F. solani & S 8 & $18.5 \mathrm{~b}$ & $9.6 \mathrm{~b}$ & $17.4 \mathrm{~b}$ & $14.0 \mathrm{a}$ \\
\hline F. sambucinum & S 5 & $18.5 \mathrm{~b}$ & $10.6 \mathrm{~b}$ & $17.0 \mathrm{~b}$ & $14.8 \mathrm{a}$ \\
\hline F. culmorum & L 3 & $18.6 \mathrm{~b}$ & $12.0 \mathrm{~b}$ & $17.7 \mathrm{~b}$ & $13.9 \mathrm{a}$ \\
\hline F. culmorum & N 2 & $19.0 \mathrm{~b}$ & $11.2 \mathrm{~b}$ & $15.6 \mathrm{~b}$ & 9.9 a \\
\hline F. culmorum & L 1 & $19.1 \mathrm{~b}$ & $11.0 \mathrm{~b}$ & $15.9 \mathrm{~b}$ & $13.0 \mathrm{a}$ \\
\hline F. solani & N 5 & $19.2 \mathrm{~b}$ & $9.6 \mathrm{~b}$ & $18.1 \mathrm{~b}$ & $13.5 \mathrm{a}$ \\
\hline F. sambucinum & $S 4$ & $19.4 \mathrm{~b}$ & $12.2 \mathrm{~b}$ & $19.4 \mathrm{~b}$ & $14.6 \mathrm{a}$ \\
\hline F. oxysporum & N 4 & $19.7 \mathrm{~b}$ & $10.4 \mathrm{~b}$ & $17.7 \mathrm{~b}$ & $12.1 \mathrm{a}$ \\
\hline F. culmorum & S 7 & $19.9 \mathrm{~b}$ & $10.5 \mathrm{~b}$ & $16.0 \mathrm{~b}$ & $16.9 \mathrm{a}$ \\
\hline F. arthrosporioides & N 3 & $20.1 \mathrm{~b}$ & $9.6 \mathrm{~b}$ & $17.0 \mathrm{~b}$ & $13.3 \mathrm{a}$ \\
\hline F. avenaceum & SK 2 & $20.4 \mathrm{~b}$ & $10.2 \mathrm{~b}$ & $16.7 \mathrm{~b}$ & $10.2 \mathrm{a}$ \\
\hline F. sambucinum & L 4 & $20.4 \mathrm{~b}$ & $10.1 \mathrm{~b}$ & $17.5 \mathrm{~b}$ & $11.1 \mathrm{a}$ \\
\hline F. culmorum & S 6 & $20.6 \mathrm{~b}$ & $9.5 \mathrm{~b}$ & $17.1 \mathrm{~b}$ & $13.9 \mathrm{a}$ \\
\hline F. culmorum & L 2 & $21.1 \mathrm{~b}$ & $10.0 \mathrm{~b}$ & $15.7 \mathrm{~b}$ & $11.8 \mathrm{a}$ \\
\hline F. arthrosporioides & S 1 & $22.2 \mathrm{~b}$ & $10.6 \mathrm{~b}$ & $15.1 \mathrm{~b}$ & $11.5 \mathrm{a}$ \\
\hline F. culmorum & SK 1 & $23.4 \mathrm{~b}$ & $10.3 \mathrm{~b}$ & $17.3 \mathrm{~b}$ & $13.9 \mathrm{a}$ \\
\hline $\begin{array}{l}\text { LSD according to Tukey's } t \text { test } \\
\text { for } \alpha=0.05\end{array}$ & & 4.7 & 2.8 & 3.4 & 4.2 \\
\hline
\end{tabular}

of these fungi from seeds, and their harmfulness consisted above all in disturbing germination ( $\mathrm{K}$ a s p e r o w i c z, 1982). The small importance of fusarium diseases on soybean in this country is probably due to the restricted area on which this plant is cultivated. In some states of the USA fungi of the Fusarium genus are of great importance in the complex of pathogens causing root rot ( $F \mathrm{r}$ e $\mathrm{n} \mathrm{c} \mathrm{h}$ and $\mathrm{K}$ e $\mathrm{n} \mathrm{ne} \mathrm{d} \mathrm{y,} \mathrm{1963).} \mathrm{Observations} \mathrm{of} \mathrm{recent} \mathrm{years} \mathrm{(} \mathrm{L} \mathrm{e} \mathrm{a} \mathrm{t} \mathrm{h}$ and $\mathrm{C}$ a r r o l1, 1982) confirm the common occurrence of $F$. oxysporum on soybean. This pathogen is known to reduce the seed yield by as much as $\mathbf{5 9}$ per cent.

The results of the author's own investigations confirmed the complexity of the etiology of fusarium blight on soybean and demonstrated that the species $F$. culmorum, $F$. sambucinum, $F$. avenaceum and $F$. solani were pathogenic for 
soybean. Earlier in Poland B i e $\mathrm{l} \mathrm{e} \mathrm{c} \mathrm{k}$ a (1978) noted that $F$. sambucinum and $F$. oxysporum caused blight of this plant. In the USA D u n 1 e a v y (1961) observed that $F$. oxysporum (described as $F$. orthoceras) was responsible for soybean seedling blight, rotting of lateral roots and browning of the vascular tissue ( $\mathrm{F} \mathrm{r} \mathrm{e} \mathrm{n} \mathrm{h}$ and $\mathrm{K}$ e $\mathrm{n} \mathrm{n} \mathrm{e} \mathrm{d} \mathrm{y,} \mathrm{1963).} \mathrm{This} \mathrm{species} \mathrm{was} \mathrm{also} \mathrm{responsible}$ for fusarium wilt of soybean as reported as early as 1965 by A r m s t r o n g and Armstrong and lately in 1982 by $L$ e th and $C$ arroll, $F$. oxysporum is also known to cause wilting of soybean in Japan ( $\mathrm{M}$ a $\mathrm{t} \mathrm{s} \mathrm{u}$ o et al., 1959). According to $S$ a $h$ a $r$ a $n$ and $G$ u p t a (1972) soybean seedlings were also infected by $F$. semitectum Berk. et Rav. In India (A g a r w a 1 and $\mathrm{S}$ a r b h o y, 1976) gradual dying of soybean plants due to $F$. oxysporum Schlecht., F. solani (Mart.) Sacc., F. graminearum Schwabe and F. equiseti (Corda) Sacc. was frequently observed. $\mathrm{V}$ a $\mathrm{rd}$ a $\mathrm{n}$ i y a (1971) noted that $F$. solani (Mart.) App. et Wr. and F. avenaceum (Fr.) Sacc. were pathogenic to soybean in the USSR.

Although $F$. culmorum, $F$. sambucinum, $F$. avenaceum and $F$. solani are considered as the cause of soybean seedling blight, not all their isolates exhibited an equal pathogenicity for the seedlings. Some of them were weakly pathogenic, of no major practical importance in causing seedling blight, like isolates of $F$. oxysporum and $F$. arthrosporioides. The differences in the pathogenicity of the isolates is a known phenomenon which has been described by $\mathrm{W}$ a $\mathrm{r} \mathrm{r}$ e $\mathrm{n}$ and $\mathrm{K} \circ \mathrm{m} \mathrm{m} \mathrm{e} \mathrm{d} \mathrm{a} \mathrm{h} \mathrm{l}$ (1973) and K l a g et al. (1978) in the case of Fusarium species occurring on soybean. $\mathrm{F} \mathrm{r} \mathrm{e} \mathrm{n} \mathrm{c} \mathrm{h}$ and $\mathrm{K} \mathrm{e} \mathrm{n} \mathrm{n} \mathrm{e} \mathrm{d} \mathrm{y} \mathrm{(1963)} \mathrm{obtained}$ 14 pathogenic isolates among 18 tested ones of $F$. oxysporum Schlecht. emend. Snyd. et Hans., and also eight of $F$. solani (Mart.) App. et Wr. and two of $F$. moniliforme Sheld., but none of the last two species were pathogenic.

The degree of pathogenicity of the tested isolates may have been affected by the experimental conditions, therefore, various methods of inoculation were applied. Good agreement of results was obtained in laboratory experiments on Petri plates, especially at tests in which the seeds were placed on filter paper imbibed with inoculum. The results of experiments performed on plates and on plant growing in the greenhouse supplement each other. The plates provided better conditions for the development of fungi, whereas in the greenhouse they were more favourable for development of the inoculated plants. The greenhouse experiment was considered as decisive for recognising the pathogenicity, especially when the plants were grown on perlite.

\section{CONCLUSIONS}

1. The investigations confirmed the pathogenicity of the Fusarium fungi for soybean seedlings. Among the twenty tested isolates belonging to six Fusarium 
species and originating from various regions of the country wide differences were found in the degree of pathogenicity,

2. Some isolates (N1, S6, L1, L2) of the species $F$. culmorum, $F$. avenaceum (SK2), F. sambucinum (L4, S5) and F. solani (S8) proved to be pathogenic for soybean seedlings. According to the experimental conditions these fungi were highly or moderately pathogenic for the inoculated seedlings.

3. The kind and degree of infection of soybean seedlings depended on the experimental conditions. In the Petri plates there were seedlings with singly infected ends of roots up to a complete destruction of the root system. In the greenhouse, however, the inoculated seedlings showed only blight of root or root neck fragments.

4. The results of the tests largely depended on the conditions of the experiment which should ensure good seed germination, seedling growth and also growth of the fungus.

5. One isolate of F. culmorum (N1) which exhibited the highest pathogenicity also inhibited the most growth of the infected plants.

\section{REFERENCES}

A g a r w a 1 D. K., S a r b h o y A. K., 1976. Efficacy of different fungicides (in vitro) to seedling rot of soybean. Indian Phytopath. 29: 458.

A r m s t r o n g G. M., A r m s t r o n g J. K., 1965. A wilt of soybean caused by a new form of Fusarium oxysporum. Phytopath. 55: 237-239.

B i e l e c k a D., 1978. Etiologia siewek soi - Glycine $\max$ (L.) Merril. M. Sc. thesis, Katedra Fitopatologii SGGW - AR.

B o o t h C., 1971. The genus Fusarium. Commonw. Mycol. Inst., Kew, Surrey, pp. 237.

D u n l e a v y J., 1961. Fusarium blight of soybeans. Proc. Iowa Acad. Sci. 68: 106-113.

D z i e g i e l e w s k a B., 1980. Mikoflora nasion soi i wpływ przechowywania na jej skład. M. Sc. thesis, Katedra Fitopatologii SGGW - AR.

F r e $\mathrm{n} \mathrm{ch}$ E. R., K e n n e d y B. W., 1963. The role of Fusarium in the root rot complex of soybean in Minnesota. Pl. Dis. Reptr. 47: 672:676.

K a s p e r o w i c z B., 1982. Znaczenie grzybów z rodzaju Fusarium w wywoływaniu zgorzeli siewek i strąków soi. M. Sc. thesis, Katedra Fitopatologii SGGW - AR.

K e r r A., 1963. The root rot Fusarium wilt complex of peas. Australian J. Biol. Sci. 16: 55-59.

$\mathrm{K}$ i $1 \mathrm{p}$ a $\mathrm{t} \mathrm{r}$ i $\mathrm{ck}$ R. A., H a $\mathrm{r} \mathrm{t}$ w $\mathrm{g}$ E. E., 1955. Fungus infection of soybean seed as influenced by stink bug injury. Pl. Dis. Reptr. 39: 177-180.

K 1 a g M. G., P a p avizas G. C., B e a n G. A., K a n z e s J. G., 1978. Root rot of soybeans in Maryland. Pl. Dis. Reptr. 62: 235-239.

L e a th S., C a i r o 11 R. B., 1982. Screening for resistance to F usarium oxys porum in soybean. Pl Disease 66: 1140-1143.

Marcink ow s k a J., Tom a 1 a-B ed n a r e k J.W., S c holle n b e r ge r M., 1982. Soybean diseases in Poland. Acta Agrobot. 35: 213-224.

Ma r c i n k o w s a J., 1984. Method of estimation of the pathogenicity of the fungus Phoma exigua var. exigua. Acta Agrobot. 37: 141-155.

M a t s u o T., S a k u r a i Y., K u r a t a H., 1959. The form names of Fusarium oxysporum and Fusarium moniliforme causing soybean wilt. Ann. Phyt opath. Soc. Japan 24: 26. (RAM 39: 451). 
N y v a 11 R. F., 1976. Colonization of soybeans by species of Fusarium. Mycol. 68: 1002-1010.

P i e t k i e w i c z T. A., 1959. Z badań nad mikroflorą nasion soi. Roczn. Nauk Rol. Seria A, 79: 1077-1090.

R o s s J. P., 1965. Predisposition of soybeans to Fusarium wilt by Heterodera glycines and Meloidogyne incognita. Phytopath. 55: 361-364.

$\mathrm{S}$ a h a $\mathrm{r}$ a n G. S., G u p t a V. K., 1972. Pod rot and collar rot of soybean caused by Fusarium semitectum. Pl. Dis. Reptr. 56: 693-694.

$\mathrm{S} \mathrm{ch}$ e n ck N. C., K i n $10 \mathrm{ch}$ R. A., 1974. Pathogenic fungi parasitic nematodes and endomycorrhizal fungi associated with soybean roots in Florida. PI. Dis. Reptr. 58: 169-173.

Se r e bre n n i k ov a N. I., 1978. Dlya zashchity posevov soi. Zashchita Rastenii 1: 23.

$\mathrm{S}$ i n g h O. V., A g a r w a 1 V. K., $\mathrm{N}$ e n e Y. L., 1973. Seed health studies in soybean raised in the Nainital Tarai. Indian Phytopath. 26: 260-267. -

Ś l a z a k J., 1978. Mikroflora nasion wybranych odmian i rodów hod owlanych soi. M. Sc. thesis, Katedra Fitopatologii SGGW-AR.

Te nn e F.D., Pra s a r t s e e C., M a c h a d o C. C., S i n c la i r J.B., 1974. Variation in germination and seedborne pathogens among soybean seed lots from three regions in Illinois. $\mathrm{Pl}$. Dis. Reptr. 58: 411-413.

V a r d a n i y a L. Y., 1971. Bolezni soi v Abkhazii. Zashch. Rast., Mosk. 16: 40-41. (R PP 50: 2048).

W a r r e n H. L., K o m m e d a h 1 T., 1973. Fusarium species in roots and soil associated with monoculture of soybeans in Minnesota. Pl. Dis. Reptr. 57: 912-914.

W u L. C., L i n Y. C., C h i u K. Y., 1964. Seedborne disease of soybean in Taiwan. Bot. Bull. Acad. Sin. 5: 105-112.

\section{Grzyby z rodzaju Fusarium jako patogeny siewek soi}

Streszczenie

Badano 20 izolatów grzybów z rodzaju Fusarium, uzyskanych w latach 1980-1982 z różnych organów chorej soi, wśród których 8 okazało się patogenami siewek soi. Najwięcej (4/8) patogenicznych izolatów reprezentował gatunek $F$. culmorum. Patogeniczne były też $2 / 4$ izolaty $F$. sambucinum oraz $1 / 3$ izolaty $F$. solani. Jedyny izolat gatunku $F$. avenaceum wywoływał też zgorzel siewek. Izolaty (2) $F$. oxysporum i (2) $F$. arthrosporioides nie byly patogenami siewek tej rośliny. Liczne izolaty wpływały na obniżenie kiełkowania nasion, a jeden $\mathrm{z}$ najbardziej patogenicznych hamował też znacznie wzrost porażonych siewek. Patogeniczność izolatów badano w szalkach na kulturach tych izolatów i na bibule nasączonej inokulum tych grzybów oraz w szklarni w podłożu torfowym i w perlicie. Stopień porażenia, a także charakter objawów chorobowych, zależał od warunków doświadczenia. Wyniki doświadczeń przeprowadzonych w szalkach i w szklarni wzajemnie się uzupełnialy. 